\title{
THE ILLUSION OF REALITY IN EMIL FERRIS’ GRAPHIC NOVEL MY FAVORITE THING IS MONSTERS (2017)
}

\author{
Sheila Hernández González
}

\section{Abstract}

By applying the concept of the illusion of reality as studied by postmodernist theorists such as Linda Hutcheon, Alison Lee and Brain McHale, this article analyses how Emil Ferris' My Favorite Thing Is Monsters (2017) creates and destroys an impression of existing at the reader's level of reality. For this purpose, it has been explored how the novel uses both internal and external elements to gain authenticity. This includes inherent aspects to the narration such as style and the diary format, but also the insertion of a secondary plot that creates its own illusion of reality and the incorporation of elements from the reader's realm that contribute to the recreation of the real world inside the fiction.

KEYwORDs: Illusion of reality, postmodernism, graphic novel, historiographic metafiction, My Favorite Thing Is Monsters, Emil Ferris.

\author{
ILUSIÓN DE REALIDAD EN LA NOVELA GRÁFICA \\ LO QUE MÁS ME GUSTA SON LOS MONSTRUOS, DE EMIL FERRIS
}

\section{RESUMEN}

Aplicando el concepto de la ilusión de realidad desde el punto de vista de teóricos postmodernistas como Linda Hutcheon, Alison Lee y Brian McHale, este artículo analiza cómo Lo que más me gusta son los monstruos (2017), de Emil Ferris, crea y destruye la impresión de ocurrir al mismo nivel de realidad que el lector. Para este propósito, se ha explorado cómo la novela utiliza tanto elementos internos como externos con el fin de ganar autenticidad. Esto incluye aspectos inherentes a la narración como el estilo y el formato diario, pero también la incorporación de un argumento secundario que genera su propia ilusión de realidad y la inserción de elementos del plano existencial del lector que contribuyen a la recreación del mundo real dentro de la ficción.

Palabras Clave: ilusión de realidad, postmodernismo, novela gráfica, metaficción historiográfica, Lo que más me gusta son los monstruos, Emil Ferris. 
If you combine horror film tradition, history of art, social awareness, and a tragic story like Frida Kahlo's the result would be Emil Ferris' mind, creator of the relatively recent debut novel My Favorite Thing Is Monsters. This 2017 first volume mixes the genres of memoir, horror story, detective story, and historical drama and it is presented in the form of the protagonist's personal diary, mainly drawn using a Bic ballpoint pen. Ferris (1962) became interested in the idea and image of monsters as a kid, when her scoliosis limited her mobility and she found herself seeking refuge in fantastic stories about outsiders like her. Before becoming an author, she, as a single mother, worked as a toys designer at night to take care of her daughter during the day. This was until 2001, when she contracted West Nile fever from a mosquito, which left the lower part of her body paralyzed and made her lose mobility in her right hand, making it impossible for her to draw and having to raise a six-years-old daughter. While recovering, she started attending the School of the Art Institute of Chicago with the idea of becoming a writer and, as she regained mobility, worked on creating her first graphic novel, which took her over six years to complete. Once the volume was finished, the ship that was hired to transport the printed copies from South Korea was held at the Panama Canal due to bankruptcy of the Chinese transportation company. For this reason, the novel could not be published in 2016 as planned, and the world had to wait until 2017. When it was finally released, however, My Favorite Thing Is Monsters received an overwhelming amount of praise not only from press and fans, but also from fellow artists like Art Spiegelman. The second and final volume has not yet seen the light, as it is expected to be published in September this year.

The book tells the story of Karen Reyes, who presents herself as a werewolf, a ten-years-old girl of Mexican, Irish and Cherokee ancestries that lived with her mother and brother in Uptown, Chicago, during the 1960s. ${ }^{1}$ The family has personal ties to a neighbour called Anka, a Jewish immigrant from Germany, that is murdered at the beginning of the narration. Karen then becomes a detective and tries to solve the mystery while at the same time deals with her own personal issues associated to the way she sees herself and is seen by others, sickness, racial struggles and the general historical environment. The novel is a bildungsroman (a coming of age story) in which we see Karen, if not physically growing, becoming more mature, losing her innocence, experimenting with her sexuality, learning about life, love, her own self, and how to deal with death. The story little by little reveals details about every character, their personality, their past and their present in a way that readers can feel a certain proximity and understand their emotions. It is not hard, moreover, to see its autobiographical aspects and the way in which Ferris projects herself on Karen Reyes. Like Karen, Ferris was raised in Uptown and, therefore, the locations represented in the novel are places well known to her. In particular,

${ }^{1}$ Particularly, in 1968, a detail the reader must fathom by the context. A key element to discover the exact date is a page at the beginning of the novel that shows the entrance to a movie theatre where Planet of the Apes (dir. Franklin J. Schaffner) had just been released. 
the Art Institute of Chicago, where Ferris parents met as art students, is one of the places Ferris most often visited, together with the Graceland Cemetery, where she went looking for monsters as a kid. Karen's beastly aspect, on the other hand, is a representation of how Ferris perceived herself as a kid suffering from scoliosis and not being canonically beautiful. In addition, she is a queer woman who identified as a lesbian for years, although now she describes herself as bisexual. This connects with Karen's struggle with figuring out her own sexuality and coming to terms with being attracted to women, as well as the general idea of feeling like an outcast. Finally, her interest and knowledge about World War II is not just the result of her own personal research for the novel but also of the conversations she used to have as a kid with Holocaust survivors that lived in her neighbourhood.

My Favorite Thing Is Monsters is an incredibly interesting and rich novel full of meaning both visually and in terms of content, two aspects that beautifully intermingle and complement each other, and, therefore, hundreds of aspects could be commented on: the symbolic use of colour or symbols in general; the line and artistic style in relation to the canon; social struggles related to race, class, sexual orientation and gender oppression; the psychology of the characters and their isolation; etc. This article, however, will focus on the way the story creates, maintains and, in some instances, destroys the illusion of reality, an aspect of the novel that allows to comment on both visual and literary aspects while at the same time making a general overview of many of the topics mentioned before.

The illusion of reality is the way in which any type of narration (be it novels, movies, theatre plays, etc.) convinces its readers or viewers that what they are witnessing and experiencing is real and that it takes place in the same reality in which they exist. The reader is aware of the fact that fictional novels are not real, but the novel itself works towards convincing us that it is, while at the same time we participate in this process of conviction by ignoring (through a suspension of disbelief) our awareness of the real world outside of the fiction as a means to enjoy the narration. While reading, you sink into a fictional world and believe what you read as a factual truth, an illusion that breaks the moment you stop reading. The creation of this illusion of reality is an important device in postmodern thought and in what Linda Hutcheon calls 'historiographic metafiction', a literary tradition that challenges the veracity of historiography and places it at the same level as fiction. As a form of metafiction, this type of literature uses self-reflexivity and self-exploration and draws attention to its status as a written artefact in order to explore the fictionality of the 'real' world and, therefore, the relationship between the world of the fiction and the world outside that fiction (Waugh, 1984, p. 3). Historiographic metafiction, then, is self-conscious and uses the modes of the historical novel and realism to challenge the separation between literature and historiography. It rejects, therefore, the idea of a universal truth, defending that truth is plural and subject to interpretation by both the writer and the reader and, in the same way as fiction, historiography imposes order on past events through a process of narrativization, transforming history into a human construct like literature, as defended by authors like Linda Hutcheon, Alison Lee and Patricia Waugh. In other words, historiographic metafiction puts into question the way we learn about the past, presenting a 
loss of faith in our ability to know a past reality and to represent it through language (Hutcheon, 1988, p. 119). Like any other type of fictional literature, historiographic metafiction works into the construction of an illusion of reality through devices such as the framing of one story within another and the inclusion of real-world figures or events that are historically verifiable, which at the same time fictionalizes these elements from the reader's level of reality by inserting them into the fictional realm (Lee, 1990, p. 46) and breaks the ontological boundary between the two levels (McHale, 1987, p. 85). This illusion of reality, however, is often establish in order to destroy it in a jarring manner using metafictional devices that draw attention to the process of writing and, therefore, to the fictionality of the novel, making the reader aware of the separation between fiction and reality.

Even though the self-conscious nature of this literary genre implies the constant destruction of the illusion of reality, for this illusion to be destroyed it needs to have been created in the first place. In the case of My Favorite Thing Is Monsters, we are not facing a regular novel, but a graphic novel, meaning that the visual aspect of the work is fundamental to the enjoyment and understanding of its message. Through its pages (and sometimes even inside the same page), many different drawing styles that range from caricature to hyperrealism coexist and function as a meaningful narrative device that informs the reader about Karen's mental state.

First and foremost, the use of realistic images collaborates in the creation of an illusion of reality in the sense that it brings its readers closer to the story. The more similar an image appears to the way we view our reality, the more we see that image as true. However, the most important aspect regarding Emil Ferris' style is the fact that this graphic novel is presented in the form of a diary, which already gives the narration a certain truthful appearance, as it can be perceived on other pieces such as The Diary of Anne Frank (1946). By this I do not mean to deny the veracity of Frank's diary, but rather point to the fact that readers do not particularly need to have all the data that proves the work to be a real diary so as to take it more seriously than they would a fictional work. In this way, Ferris creates a fiction in a format that is usually associated to veracity. However, Ferris is not content with simply stating that My Favorite Thing Is Monsters is a diary, but she goes as far as to give it the physical appearance of a lined spiral notebook that has been written and drawn on, adding to it a sense of authenticity. In addition, the events narrated by Karen never truly seem impossible or unbelievable. It is true that at times the narrator incorporates magical elements and that she presents herself as a beast, but it is easy for the reader to perceive that every detail that seems impossible is just the result of Karen's imagination and that we need to see beyond that to a deeper meaning that is part of a feasible story.

As it has been established, what we have here is a diary. But what does that mean? It means that absolutely everything shown to us through drawings, though possible, is completely subjective and a mere representation or translation of the way Karen perceives her reality and the way she feels about that reality, putting into question her reliability as a narrator. This way, through drawings and different styles, Karen portraits her emotions and mental state, which explains the existing contrast between drawings that can even share a page. While in some pages we see very 
realistic and detailed pieces, in others we find cartoony drawings with an undefined line that seems to have been done by a shaking hand. A clear example of this is the way in which, in one of her visits to the Art Institute of Chicago, Karen enters one of the paintings ${ }^{2}$ and interacts with a figure that was almost indiscernible from the outside: a demon that makes her uneasy by forcing her to question her family's innocence in relation to Anka's murder. Throughout this conversation, her state of mind starts to become unstable and she cannot think clearly. Karen's stress in this situation is represented through undetailed drawings, a lack of order and definition, and the use of black marker, a tool with a thicker and darker line than the usual ballpoint pen. In fact, this is the only instance in which Karen uses that black marker instead of a pen. This subjective perspective can also be perceived when, at the beginning of the graphic novel, her brother Deeze enters a café and is harassed by a racist lady. Here, the way Karen draws both characters speaks of the ways she sees them: While Deeze is represented as a handsome, healthy and calm man, the old lady has a grotesque and generally negative appearance. This is accomplished not only by the contrast between the realist Deeze and the caricatured lady that resembles a gargoyle, but also through the use of colours. The lady is represented in black and white, as is the whole place, while Deeze stands out because of a richness in the use of colours. This is obviously not the only instance of the use of colour as an element to show a particular perspective, though. Through the entirety of the novel, we see how Karen uses colours to create a contrast with the rest of the scene that is usually drawn in black pen, but also to express moods and emotions. Anka, for example, is almost always drawn in blue in order to portray her sadness. In fact, blue is constantly used to demonstrate the sadness of characters and scenes, and it often changes in intensity and shade depending on the strength of that sadness.

In general, the whole concept of the diary and its connection to monsters is a projection of Karen's vision. She represents herself as a monster because that is how she is perceived not only by herself but also by those around her due to her marginal position as the queer daughter of poor immigrants. It is because of this that she portrays her friends, who are also in marginalised positions, as monsters too, while the true monsters (Nazis, abusers, homophobes, etc.) are always shown as humans in order to question prejudices and preconceived ideas. In addition, the use of Karen's perspective implies the existence of a much broader reality My Favorite Thing Is Monsters does not portray and that is unattainable for readers. In other words, Karen's perspective is limited, she does not know everything and the information that reaches the reader is a portion of reality selected and translated by her. This can also be associated with postmodernist thought in the sense that the work of fiction (as well as historiography) is unable to fully represent reality, its complexity and multiplicity, portraying a single perspective, as it is argued by historiographic metafiction. This subjective nature is, moreover, associated with the lack of order that can be perceived through the graphic novel. My Favorite Thing Is Mons-

2 The Temptation of the Magdalene (1617), by Jacob Jordaens. 
ters is not a very traditional comic book when it comes to style and a great part of the volume does not even have panels or speech balloons. This contributes to the image and veracity of the diary, giving it the appearance of a sketch notebook but also portraying how human minds function: disorderly and nonlinearly. The lack of panels together with drawings that mix with one another and the generally chaotic atmosphere imitates the way our brain works and how we think about many things at the same time, jumping from one idea to another. The diary, therefore, is nothing more than a depiction of Karen's inner world. However, this is not a device that Emil Ferris invented for this fictional diary but something that literary authors like James Joyce, Virginia Woolf and William Faulkner tried to accomplish during the early $20^{\text {th }}$ century: to represent the stream of consciousness in order to represent reality completely and truly as our mind perceives it instead of imposing a chronological order on our thoughts. This device, therefore, contributes from an early $20^{\text {th }}$ century perspective to the creation of an illusion of reality.

As it has been established, the diary format is a tool that contributes to the creation of the illusion of reality in many ways. However, it is highly interesting how this format can also easily destroy that illusion. In multiple occasions the reader can witness how the story is interrupted and, in a metafictional manner, our attention is drawn to the fictionality of the narration or, at least to its nature as a human construct. There is a moment, for instance, in which Karen is completely absorbed in her thoughts and, while she is portraying her ideas in the paper, she is interrupted by the phone that starts ringing. Here, the phone is an external element that is not part of the comic book and does not even physically appear, but its sound is manifested on the page and interrupts Karen's actions, taking her away from the reader. This breaks not only the flow of the narration, but also the illusion of reality as it makes readers aware of the fact that My Favorite Things Is Monsters is a diary written by a kid, and also brings attention to the existence of an external reality in her life that we are not aware of, as it has been stated. In other words, the reader realises that the story is a construct created by a kid by selecting events from her life and that there is a wider "reality" that she is not including in her narration. A similar incident occurs when, already reaching the end of the volume, Deeze mentions the notebook that Karen uses as her diary and suggests she should spend less time drawing. In doing this, Karen's brother is referring from inside the story to the physical object that the reader is holding outside of the narration, once again drawing attention to its fictionality or, at least, its distance from the reader's reality and, therefore, breaking the illusion. Not only that, but Deeze even talks to Karen about his concerns regarding the way she portrays herself as a monster and forces her to admit that what she draws is not her real appearance, making the reader question her reliability as a narrator. In this moment of honesty, revelation and facing fears, Karen shows her real face for the first time, a reality that existed on the fictional realm but was hidden to those outside of the narration.

Heretofore, this analysis has dealt with the illusion of reality focusing on elements that are inherent to the work per se such as style, form and perspective. However, one of the most frequent and common ways in which historiographic metafiction creates the illusion of reality is by inserting into the narration certain exter- 
nal elements that give the story a sense of veracity and authenticity. In My Favorite Thing Is Monsters, as readers advance in the narration, more and more information about the characters is revealed and accessible. This way, through flashbacks, we learn about Anka's past, which constitutes a secondary story within the main plot revolving around Karen's attempts at solving the murder. This additional narration is presented through Karen, who listens to old tapes of an interview Anka had done in the past. While she is listening to these tapes the flashback takes us to Anka's childhood and early adult years in Nazi Germany. As a result, while these tapes are playing, the main plot disappears in the reader's mind as we are immersed in the secondary plot that has an illusion of reality of its own, often destroyed when Karen stops the tapes. In other words, just like the main story has an illusion of reality that makes the reader forget about the external world, the secondary plot creates an illusion that makes us forget about the main plot that surrounds it, creating an additional and deeper realm. Apart from the instances in which Karen stops the tapes by her own wishes, this illusion of reality is abruptly broken when external factors from the main plot seep into the events narrated by the tapes. For example, comments made by Karen to the readers overlap with the pages belonging to the secondary story, and the same happens when Deeze calls Karen while she is listening to the interview and his voice appears on pages showing 1940s Germany. This interruption not only destroys the illusion of reality, but also breaks the flow and linearity of the narration, once again resembling real life in its lack of order and the way we perceive it, as it has been discussed.

More remarkable are the multiple ways in which the story gains authenticity by taking elements from the reader's realm. The inclusion of historical events and figures, places from the reader's realm, etc. convinces the reader of the veracity of the story. As it has been mentioned, the narration takes place in Uptown (Chicago) and, due to Ferris' link to the city, locations and important buildings represented in the novel are taken from our reality and accurately portrayed. Moreover, the story takes place during the 1960s in the context of the Civil Rights Movement, which is closely connected to Chicago and, particularly, to Uptown, an area that experienced an economical decline caused by the Great Depression from the 1930s onwards and became the home of low-income immigrants, a situation that eventually caused crime to rise during the 1960s (Seligman, n.d., para. 3). This is the reason why many historical figures play a part in the story, whether their role is mainly passive or they actively affect the narration. Some of them, like Emiliano Zapata (1879-1919) and Diego Rivera (1886-1957) are merely mentioned because of Deeze's admiration towards them. The same happens with Al Capone (18991947), a figure historically connected to Chicago, who is only referred to through a cat that is named after him. Others, like Martin Luther King (1929-1968) and John F. Kennedy (1917-1963) are mentioned or appear in a subtle manner, ${ }^{3}$ but have an influence on the characters. Both Kennedy and King's deaths are traumatic expe-

${ }^{3}$ King, for example, is shown on a television screen a couple of times. 
riences for many of the characters that, being in an unprivileged position, equate the events to a loss of hope. Saint Cristopher, referred to as the Werewolf Saint, technically does not have an active role either but is of great emotional importance for Karen as it helps her feel less alone and guides her. In fact, there is only one historical figure that plays a truly active role in the narration ${ }^{4}$ : Kate Warne's ghost appears to Karen when she is intoxicated with a cannabis-infused brownie. She interacts with Karen, telling her the story of how she became the first female detective in history, and helping her face and resolve her uncertainties. This interaction causes Warne to become an active character that has an impact on the story through its protagonist.

Other elements from the reader's realm that are assimilated by the narration include specific books, brands, movies, etc. that do not play any role in the story other than filling the gaps but that, nonetheless, contributes to the recreation of the reader's reality. Art and history of art, however, are central elements in the novel. Karen is a kid who, due to her brother's influence, has a great interest in studying and creating art, as the existence of the diary itself demonstrates. She is constantly visiting the Art Institute of Chicago and mentioning artists, specific works of art and artistic movements. For her, art is not just a means of expression, but a model to understand her reality. Art, therefore, is very present in all aspects of the narration and it has two main functions. On the one hand, Karen uses artistic elements on her daily life to compare her reality to the characteristics of art. In other words, she perceives reality from an artistic point of view and therefore, she is constantly describing what she sees and feels in specifically artistic terms. For example, when she finds her mother cleaning the murder scene, she describes the moment as follows: "The color palette of mama's rubber gloves and Anka's blood combined with the metal smell made me think of a painting by Magritte" (p. 46). And, similarly, she states that "basements usually smell like Surrealism. But kitchens and gardens almost always smell like Impressionism" (p. 72) and that, when she found herself in an incredibly stressful situation, she was so overwhelmed by everything around her that she "felt like [she] was trapped in an abstract painting" (p. 237). These are just a few examples, but the list goes on as she compares Sam (Anka’s husband) to Picasso's blue guitar player or connects the taste of cannabis-infused baked goods to a painting by Salvador Dalí. It seems like Karen experiences reality through a

4 There is another character, however, that might be based or inspired by a historical figure. There is a resemblance in name and appearance between Schutz, the German paedophile with whom Anka lives until she becomes "too old for him", and Johannes Heinrich Schultz (18841970), a psychiatrist and psychotherapist. Both men were educated and influential during the Nazi regime. Schultz, moreover, specialised in sexual education, sterilization, euthanasia and homosexuality, and worked for the fascist regime exterminating mentally handicapped individuals and "curing" homosexuals, which allowed him to save some people from concentration camps by declaring them "cured", similarly to what Schutz would do for Anka. Therefore, both men were generally horrible people who did acts of kindness and whose lifes were marked by sexual misconduct in the case of Schutz and the observation of homosexuality by Schultz, one being an aberration today and the other being considered so at the time. 
sort of artistic synaesthesia and uses that to illustrate her inner world of emotions and perceptions, another personal trait she shares with her creator.

On the other hand, some works of art are replicated by Karen inside the graphic novel in a detailed manner and function as active elements in the narration, mostly revealing information about characters and their past as well as leading to clues of Anka's murder. In fact, it is because of The Nightmare (1781), by Henry Fuseli, a painting that her brother described as "history's first horror comic cover" (p. 49), that she starts thinking about Anka's past and how it might be relevant in relation to her murder. Often, these pieces are known to Karen because of her frequent visits to the Art Institute of Chicago. In the course of this narration, she visits the institution in two occasions. Firstly, with her brother in the form of a flashback, meaning that their visit did not take place in the time lapse of the story, but in the past. In this occasion, though many pieces are portrayed, the most significant one is Saint George Killing the Dragon (1434-1435), by Bernat Martorell, a painting that makes Karen think about his brother and his layers as a multidimensional person. This experience tells the reader about the relationship between the siblings and the influence that Deeze has on Karen. Before the tour through the museum, Karen even explains the theory behind the symbol of vesica piscis, a mathematical shape formed by the intersection of two disks with the same radius in a way that the centre of each disk lies on the perimeter of the other. This theory was explained to her by Deeze and it not only shows the weigh that art and its more theoretical aspect have on the story, but it is also significant in the sense that Deeze uses this theory as an analogy for human relationships, once again using art as a medium to understand the characters in the story. Her second visit takes place later in the graphic novel and, in this occasion, Karen is accompanied by her friends Sandy $y^{5}$ and Frank. The event has two main purposes: firstly, to learn about Frank's interests and sexual orientation; and secondly, to find clues about Anka's murder. The reason why Karen decides to go to the Art Institute of Chicago in this occasion is because when she saw Anka the morning before she was murder, the atmosphere reminded her of The Temptation of the Magdalene (c. 1616-1617), by Jacob Jordaens, and it is in this occasion that the encounter already mentioned between Karen and a demon takes place inside the work of art, an experience that helps the protagonist think about possible explanations she was trying to ignore.

Moreover, another painting that appears in the story and has an important influence is The Blessed Guillaume de Toulouse Tormented by Demons (1657), by Ambroise Frédeau, which teaches Karen that there are good and bad monsters and the difference between the two, a topic explored through the whole book. The

5 Sandy, however, is probably an imaginary friend or a ghost. There is evidence in the text to believe that only Karen can see her and the she is a product of her imagination, often saying what is in Karen's subconscious. Sandy seems to live in an abandoned apartment and, though Karen can see her through the windows, she is never home when she goes looking for her. In addition, Sandy claims her parents are dead and that she lives with her aunt and uncle, but these people never appear in the story and Frank always seems confused when Karen mentions her. 
main idea is that fictional monstrous creatures are often considered as evil and prosecuted just because of their appearance, an aspect they cannot control, while the real evil monsters are human beings that seek power by controlling the masses through fear. Finally, also remarkable is that, at the end of this volume, the protagonist falls asleep and, in her dreams, she jumps from one painting to another. The graphic novel, then, presents a great number of paintings that are recreated in full detail on its pages, adding to the visual richness of the story and, moreover, participating in this creation of an illusion of reality since the realistic representation of pieces of art easily recognizable for the reader creates a closeness to the story, making us believe that the events narrated take place in the same realm in which we (an those pieces of art) exist.

The aforementioned, however, are just very specific aspects of real life that the novel borrows to recreate, inside the fiction, the reality experienced outside the fictional universe. There is, however, a much more general aspect taken from real life that, moreover, justifies the inclusion of historical figures: The social context. As we know, the story takes place in 1960s Chicago and the significance of this goes beyond a random setting. This stage allows the writer to include many social issues related to citizens in marginal positions. This way, the book shows a historical context characterized by racism, police brutality, crime, immigration, homophobia, poverty and all sorts of discrimination, showing, in the process, what individuals are willing to do to survive (prostitution, violence, drugs, etc.). When the reader looks at the pages and sees the great diversity of characters (both main and secondary) and the representation of the activity in the streets of Uptown, he is not only reading a story, but being exposed to the reality of a specific area that, put in context with the figures of Martin Luther King Jr. and John F. Kennedy, has a greater national significance in an era of struggle. This representation of a past reality bring us closer to the story and gives it a sense of authenticity, making the reader believe that since the context is real, the narration might be real as well. However, from the point of view of historiographic metafiction and as it has been argued by Allison Lee (1990), it also fictionalises the historical figures and events by inserting them in the fictional universe, putting into question the veracity of history and the line that separates fiction from real accounts.

This, nonetheless, is not only observable in a general overview of the neighbourhood, but it can also be perceived in the specific individuals that are constantly affected and isolated by race and class. The story presents a lower-class female protagonist, the daughter of immigrants that has an absent father and, as it is gradually revealed to us, is part of the LGBTQ+ community. Her brother faces racist violence and discrimination due to his Mexican physical features; her friend Frank, who is African American, has been mutilated and faces discrimination even inside of his community due to his sexual orientation and gender expression; her mom faces a fatal disease without the economic means to afford treatment; and Anka was a Jew escaping from Nazi Germany that suffered from PTSD. In addition, the story about Anka's past in Berlin included inside of the main plot obviously deals with social issues regarding the struggle of Jewish people during the 1930s and 1940s as well as the role of prostitutes in society and child prostitution. It seems clear that 
what Emil Ferris is doing by interlocking these two narrations is to create a parallelism between the United States during the 1960s (especially in marginal areas such as Chicago) and Nazi Germany, implying that there are certain characteristics rooted in the system of American society that are reminiscent of a fascist regime.

In conclusion, it has been demonstrated that My Favorite Thing Is Monsters convinces the readers of its authenticity and creates an illusion of reality, a device used in fiction but particularly studied by postmodernist literary theory, through different devices inherent to the medium and form used or incorporated into the narration. The fact that it has the appearance of a diary collaborates in this illusion and implies a completely subjective point of view, a translation of reality through Karen's eyes, which also allows to show her stream of consciousness, therefore making a more accurate representation of reality as humans experience it. A secondary story inside of the main plot also creates its own illusion of reality, making the reader forget about the story that surrounds it. The illusion, moreover, can be destroyed in both these narrations (main and secondary), usually through external elements and by bringing the reader's attention to the fictionality of the diary. The illusion is also supported by the incorporation of historical figures and places, paintings by important figures in the history of art and other elements (brands, movies, etc.), some of which play a rather active role in the narration, having an important impact on the characters and the development of the story. Finally, the representation of Chicago's social context and diversity during the 1960s gives the narration authenticity and, merged with the secondary plot about Anka's childhood, creates a parallelism between The United States and Germany under fascist rule. Though it might seem like this parallelism is a thing of the past and refers only to The United States in a particular era, the truth is that little has changed in America and those values that were rooted in a system of oppression during the 1960s still remain, especially visible under Donald Trump's administration. Ferris wrote this story that perfectly mixes the visual and the literary keeping in mind those aspects of America that, while growing up in Chicago, reminded her of a fascist regime and, in her own words she "thought [she] was writing a story about the past" (E. Ferris, interview, October 1, 2017) but the truth is she was not. It is true that $M y$ Favorite Thing is Monsters includes certain presumably fantastic elements in order to confuse the reader, but the truth is that none of its monstrosity escapes our reality, none of it is impossible or unbelievable. And for this reason, the illusion of reality, in this case, is more than a mere illusion. 


\section{LIST OF REFERENCES}

Constenla, T. (2018, May 24): «Mis amigos son monstruos», El País. Retrieved from https://elpais. $\mathrm{com} /$.

FErris, E. (2017): My favorite thing is monsters. Seattle, WA, Fantagraphics Books.

Foucault, M. (1977): «Nietzsche, Genealogy, History», in D.F. Bouchard (ed.): Language, Counter-Memory, Practice: Selected Essays and Interviews (pp. 139-164), Ithaca, NY, Cornell University Press.

Hutcheon, L. (1988): A poetics of postmodernism, London, Routledge.

Jennings, D. (2017, February 17): «First, Emile Ferris was paralyzed. Then her book got lost at sea». The New York Times. Retrieved from https://www.nytimes.com/.

Lee, A. (1990): Realism and power: Postmodern British fiction, London, Routledge.

McHale, B. (1987): Postmodernist fiction, London, Routledge.

SmallPressExpo (2017, October 1): SPX 2017 Panel-Emil Ferris: My Favorite Thing is Monsters [Video file]. Retrieved from https://www.youtube.com/watch?v=uL7LMFR5Kvw.

Thielman, S. (Interviewer) \& Ferris, E. (Interviewee). (2017): Emil Ferris: 'I didn't want to be a woman-being a monster was the best solution. [Interview transcript]. Retrieved from The Guardian online newspaper https://www.theguardian.com/books/2017/feb/20/emil-ferrismy-favorite-thing-is-monsters-graphic-novel.

Umile, D. (2017, January 18): "Creatures invade 1960s Chicago", in My Favourite Thing Is Monsters. Chicago Reader. Retrieved from https://www.chicagoreader.com/.

Vine, C.N. (2009): Psychology under the Third Reich. Retrieved from Worcester Polytechnic Institute. (URN E-project-102609-144251).

WAUGH, P. (1984): Metafiction: The theory and practice of self-conscious fiction, London, Routledge. 